\title{
Impact of Choice based four tracks project system on development of final year Engineering students and challenges faced during implementation: Case Study
}

\author{
Mr. Ganesh L. Suryawanshi ${ }^{1}$, Dr. Sachin K. Patil ${ }^{2}$, Dr. Mrs. S. S. Kulkarni ${ }^{3}$ \\ ${ }^{1}$ Mechanical Engineering Department, Rajarambapu Institute of Technology (RIT), Rajaramnagar, 415414, India \\ ${ }^{2}$ Mechanical Engineering Department, Rajarambapu Institute of Technology (RIT), Rajaramnagar, 415414, India \\ ${ }^{3}$ Civil Engineering Department, Rajarambapu Institute of Technology (RIT), Rajaramnagar, 415414, India. \\ ${ }^{1}$ ganesh.suryawanshi@ritindia.edu
}

\begin{abstract}
Being an autonomous institute, Rajarambapu Institute of technology (RIT), Rajaramnagar decided to start choice based four tracks of projects for final year engineering students from the year 2017-18 to develop them globally competent. As per this system students can opt one choice from industry internship \& projects (IIP), undergraduate research experience (URE), Entrepreneurship development (ED) and regular capstone project $(\mathrm{CP})$ by their choice. Present work focuses on choice based four track project system, its impact on student's career, challenges faced during implementation from student and institute perception and major actions taken to overcome the challenges. To analyse the outcomes of four track project system, survey of students and their evaluators were conducted. It was observed that students who opted IIP track, developed their skills like technical competency and interpersonal skills. Institute succeeded to improve the placement from $89 \%$ to $63.05 \%$. From survey and evaluation of URE opted students, it is observed that selflearning ability, self-confidence and critical thinking improved at satisfactory level. This helped the students to build their resume. In last three years 20 URE opted students secured admissions easily at foreign universities after clearing the entrance test. Under ED track, students developed entrepreneurial self-efficacy and entrepreneurial characteristics. 19 students started business and 21 students joined the business of their parents in last three years. Students who opted CP track succeeded to develop skills like team work, innovative thinking, and time management. Overall, it has been observed that admission cut off marks of institute have been increased by 10 to $30 \%$ from the year 2017-18 to 2019-20.
\end{abstract}

Keywords Four track, internship, research, entrepreneurship, capstone project, challenges.

\section{Introduction}

Today's competitive world is demanding industry ready students from engineering institutes. There are around 4282 Engineering Institutes in India. More than 30 Lakh students of various streams get pass outs from these institutes every year. In this scenario, engineering students need to face huge competition while seeking a job as per their wish. Hence, teaching learning methodologies play a vital role in the development of engineering students
(Gashaw,2019). As per the curriculum of engineering education, it is expected to do a major project by final year students. Moreover, students need to do a project in a group on a particular problem concerned to respective engineering domain. Though this practice is beneficial to develop a skill like critical thinking, analysis, team work, project management etc. (Waychal,2016), students are not exposed to gain real work experience. In current Engineering education system, entrepreneurship education is believed to be complementary. Some of the students wish to open a start ups after graduation but they don't get required knowledge and experience during the graduation.

It is necessary to shift a focus of the curriculum more on Experiential learning models to create a better opportunity in real work of world. Experiential model includes cooperative education, internships, service learning, research, study abroad, fieldwork and other educational and professional experiences like entrepreneurship development (Gashaw,2019). All these experiences are to connect, what is being taught in the classroom and what will be expected in the job. In Cooperative education, institutes and employers work hand in hand so that students can take the lessons in class and apply it to the workplace. This boosts the workplace experience and decision-making ability (Jung and Lee,2017). Moreover, in internship students gain work experience but it is for limited time. Cooperative experiences are salaried, supervised by a professional who has followed the same career path of the student. The major difference in cooperative education and internship is that, in cooperative students are treated as a full time or part time employees and they are paid for it. In case of internships students work for free or less pay. Literature survey depicts that most of the institutes prefer, internship programs of four to six weeks in the four years of degree. Cooperative education and internships can heighten awareness of community issues, motivate students to create opportunities, embrace new ideas, and give direction to positive change (Gol et al.,2001). A successful internship can give valuable information in making the decisions about the direction of future studies or employment. An internship is an opportunity not only to use and develop industryrelated knowledge and skills, but also to enhance some of the skills that are transferable to any professional work setting. Despite of this importance of internship in 
development of students, there is a consensus that, many of institutions face complications to integrate internship in the regular curricula (Parishani, Khorooshi ,2016) (Renganathan et al.,2012). Several researchers have studied the benefits of internships, however, challenges to implement these activities from students and institutes perception is scarce. Internships should be well planned right from allocating the industries, enough internship period, proper supervision and guidance, support to interns in terms of funds etc. (Gashaw,2019). Otherwise there may be many challenges which institutes and students can face.

Apart from industrial experiences, students wish to engross themselves in the research field which would be beneficial to society and human beings. Research experience for undergraduates is of great importance not only for conducting research on a topic that has impact on a current research activity, but also as a tool to enhance undergraduate education (Lutz and Schachterle,1996). For the engineering technology students, research experiences allow them to carry out in-depth study of engineering concepts, while emphasizing hands-on experiences and practical applications. Participating in research projects strengthens the student's resume, and fulfils the requirements of present day employers, who demand sound engineering skills in their employees.

Changes in the economy and workforce needs entrepreneurship development training to engineering students (Gerba,2012). This education is considered as complementary for engineering students (Duval-Couetil et al.,2012) (Täks et al.,2014). Students who have characteristics towards entrepreneurship, should get exposure during degree program. Although more engineering students are being exposed to entrepreneurship education, minimal research has examined engineering student attitudes toward it, its impact on their learning, or professional competence (Kim and Park, 2019). Literature survey emphasizes that working in research and development task of manufacturing industries is viewed as a glamorous career for the brightest engineering graduates, but the number of attractive job offers has been declining for many years. Hence, it is current need to motivate engineering students towards entrepreneurship. Engineering students appear to be very well suited to become entrepreneurs, but they should get proper guidance to develop their career as entrepreneur.

Looking to current global scenario, Rajarambapu Institute of Technology (RIT), Rajaramnagar decided to put forth a step in experiential learning model. Initially, institute conducted a survey of 500 students. It was observed that, $65 \%$ students had a wish to work for medium or large size companies after graduation. $15 \%$ students showed willingness to complete higher educations in IIT's, NIT's and other reputed technical universities. 6\% students were willing to complete post-graduation in abroad and remaining $4 \%$ students showed interest to develop career in entrepreneurship. Hence, being an autonomous institute, RIT, Rajaramnagar decided to start choice based four tracks of projects for final year B. Tech students in the year 201718. As per this system students can opt one choice from industry internship \& projects (IIP), undergraduate research experience (URE), Entrepreneurship development (ED) and regular capstone project (CP) by their choice. Present work focuses on choice based four track project system, its impact on students' career, challenges faced during implementation from student and institute perception and major actions taken to overcome the challenges.

\section{Choice based four track system at RIT}

University Grants Commission (UGC) and Shivaji University Kolhapur accorded the status of academic autonomy to RIT from the year 2011-12, which we looked towards a great opportunity to design curriculum sensitive to needs of Business and Industries. RIT took many initiatives to foster excellence in academics, research, knowledge creation and delivery to develop sociallyresponsible professionals. Choice Based four track system is one of the major initiatives. Under this system final year students of engineering can opt one track from the following

$\begin{aligned} \text { i. } & \text { Industry internship and projects (IIP) } \\ \text { ii. } & \text { Undergraduate research experience (URE) } \\ \text { iii. } & \text { Entrepreneurship Development (ED) } \\ \text { iv. } & \text { Regular Capstone project (CP). }\end{aligned}$

\section{A. Industry internship and projects (IIP)}

Internship is designed to expand the depth and breadth of academic learning of students in their areas of study. It is an opportunity for students to receive experience in applying theories learned in the classroom to specific experiences in the community and work world. Under IIP track, students are expected to be associated with industry for minimum 20 weeks in the eighth semester. Student works in the industry for this period. During this Internship it is expected that, students should identify the problems arising in the industry related to Engineering and they need to give a solution to the company. In the eighth semester of engineering, total 24 credits are allotted to this track. Out of these, 10 credits are allotted to internship, 11 credits are allotted to project and 3 credits are allotted to online learning course. Internship and project are a separate parts of IIP. Under internship, students are expected to,

i. Examine the functioning of the company in the terms of inputs, transformation process and the outputs (products and services)

ii. Develop an attitude to adjust with the company culture, work norms, code of conduct.

iii. Recognize and follow the safety norms, Code of conduct.

iv. Demonstrate the ability to observe, analyse and document the details as per the industry practices.

v. Interpret the processes, systems and procedures and to relate to the theoretical concepts- studies.

vi. Improve the leadership abilities, communication.

vii. Demonstrate project management and finance sense

Under project students are expected to,

i. Identify the project/problem in the domain of program relevant to the company. 
ii. Collect the information to the pertaining to the problem identified.

iii. Analyse the information using the statistical tools/ techniques.

iv. Suggest the feasible alternative solution and select the best solution.

v. Present the solution to the company and seek assistance in the implementation.

vi. Measure the impact of the project on the performance of company/department.

Students are expected to select one online course from various platforms to earn three credits. Students can select this online course related to their project domain. Under IIP track, liberal learning course of one credit is included in the seventh semester of engineering curriculum. To earn this credit, student should select non-technical online course like professional skill development, work ethics etc.

\section{B. Undergraduate Research Experience (URE)}

Research experience for undergraduates is of great importance not only for conducting research on a topic that has influence on a current research activity, but also as a tool to develop undergraduate education. For the engineering technology students, research experiences allow them to carry out in-depth study of engineering concepts, while emphasizing hands-on experiences and practical applications. Participating in research projects strengthens the student's resume, and fulfils the requirements of present day employers, who demand sound engineering skills in their employees.

In the eighth semester of engineering, total 24 credits are allotted to this track. Out of these, 17 credits are allotted to research project, 4 credits are allotted to Research methodology theory and practical course and 3 credits are allotted to technical course related to project. This technical course may be online course or self-study course designed by guide. Under URE track, students are expected to,

1. Investigate the technical literature.

2. Design a research problem and develop a methodology.

3. Develop and implement an advanced original research or creative project.

4. Develop the ability to explain the conceptual viability of the project and describe the major components involved.

5. Develop the ability to explain how the project will impact the relevant body of work.

6. Develop advanced discipline-relevant skills and competencies.

7. Construct accurate record of research performed.

8. Write a research report and paper.

Under this track students are likely to publish research papers in reputed journals or conferences. It is necessary condition to become eligible for end semester examination of URE. In Seventh semester of Engineering one credit is allotted to URE synopsis. Here students who opted URE track are expected to publish review paper on selected research topic.

\section{Entrepreneurship Development (ED)}

For entrepreneurship to take roots in the country and to realize the dream of Make in India, it is extremely significant to orient the present generation and the academia towards this discipline. This program features three modules covering the central challenges of corporate entrepreneurship:

i. Ideation: How to find great ideas;

ii. Incubation: How to develop those ideas into a business;

iii. Acceleration: How to launch this new business so that it can merge successfully with the corporate parent.

Curriculum of ED track is developed with an objective that, the students can develop and systematically apply an entrepreneurial way of thinking, which will allow them to identify and create business opportunities that may be commercialized successfully. In the eighth semester of engineering, total 24 credits are allotted to this track. Out of these, 16 credits are allotted to Project Report on Product/start up with complete techno economic feasibility assessed by funding agencies and approved for funding, 3 credits are allotted to Project feasibility, 3 credits are allotted to Commercial aspects of project course and one credit is allotted to ED program. In ED program, RIT organizes eight days workshop for students and their mentors. Successful entrepreneurs are invited to give expert talks to guide students. Under ED track, students are expected to,
i. Determine distinct entrepreneurial traits
ii. Recognize the parameters to assess opportunities and constraints for new business ideas
iii. Apply the systematic practice to select and screen a business idea
iv. Design strategies for successful implementation of ideas
v. Design a business plan

In Seventh semester of Engineering one credit is allotted to project feasibility report. Here students who opted ED track are expected to do market survey and put forth an idea of start-ups.

\section{Regular Capstone project (CP)}

Under Regular capstone project students must do a project in a group. Moreover they need to learn Program and open electives as per their choice. In the eighth semester of engineering, total 24 credits are allotted to this track. Out of these, 16 credits are allotted to Project. Remaining credits are allotted to program and open electives. Under CP track, students are expected to,

i. Comprehensive and up to date survey of literature related to study of phenomenon

ii. Design of any equipment and or its fabrication and testing.

iii. Critical analysis of any design or process for optimizing the same

iv. Experimental verification of principles used in applications 
In Seventh semester of Engineering, one credit is allotted to CP synopsis.

\section{Implementation and Challenges faced in choice based four track system \\ RIT took a decision to start four tracks system of} project from 2017-18 and collected choices of the students to know their inclination. It was observed that around $80 \%$ students were interested to take IIP track. $10 \%$ were interested in CP track and remaining $10 \%$ students were interested in URE and ED track. Initially, it was really difficult, to allow $80 \%$ students for internship. So, decision was taken to conduct allotment procedure. RIT conducted aptitude test followed by personal interviews. Based on this process, allotment of students for respective track was done. This procedure was conducted just before start of seventh semester of engineering. RIT is following same allotment procedure from 2017-18 to till now. Statistics of four track allotment is given in figure no. 1 .

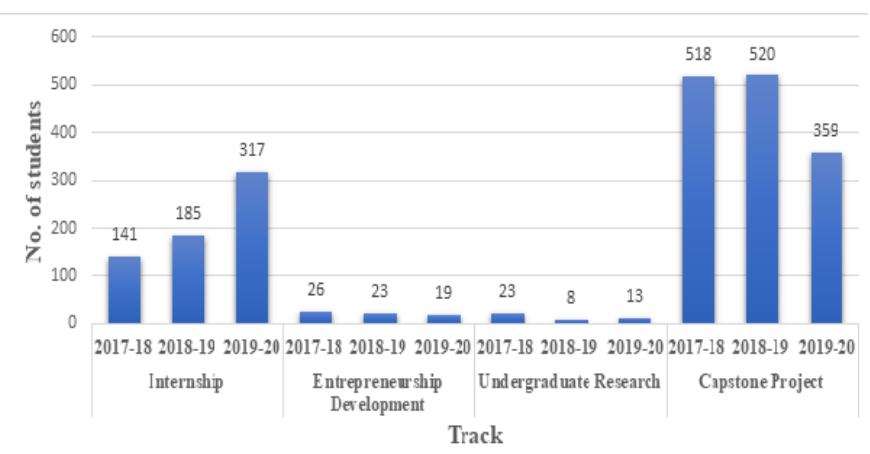

Fig.1 Statistics of four track allotment (2017-18 to 2019-20)

A. Implementation and Challenges in IIP track

In 2017-18, institute decided to allot IIP track to $30 \%$ students. As it was first year of implementation, institute was not aware of challenges coming. Institute faced following challenges while implementing IIP track

i. Identifying the industries and convincing them to select students for internship.

ii. Initially demand for this track by students was huge. More than $80 \%$ students demanded this track.

iii. Students who were opted IIP track, demotivated after joining the industry. Some of the students faced problems like lack of attention and guidance from industries, health issues, family problems, economic crises as some of the industries were not ready to give stipend to these students. So, such students insisted to change their allotted track.

iv. Along with internship and project, students were expected to do technical online course. Some of the students felt burden to study this course because, working hours in the industry remains 8 to 10 hours and they were not getting enough time to study.

To overcome above mention challenges, RIT put forth following steps from 2018-19. i. Training and placement team worked hard for six months before the start of eighth semester and identified the industries for internship. Institutes signed Memorandum of understandings (MoU's) with some of the foreign universities.

ii. As demand to this track was huge, institute conducted selection procedure. Then analysis of student interests was done to allot them appropriate track.

iii. Students who were confused and insisted to change the track were counselled. Institute decided to conduct evaluation of students thrice in a semester. For this purpose, institute mentors were assigned. These mentors visited the industries to take the follow up of students progress. Institute provided evaluation rubrics to industries, which helped them to guide the students. Institute provided hostel facilities in the cities where students were doing internship.

iv. Students were asked to select online course in lined with their project work. Thereafter Students started to take interest while studying technical online course.

B. Implementation and Challenges in URE track

Students who wish to do masters in abroad, are expected to opt URE track. It helps students to build their resume from research angle. Institute faced following challenges while implementing URE track.

i. Most of the students found difficulty to complete project on time. Some of the students found difficulty in getting the results as per the hypothesis which they presented earlier in the synopsis.

ii. Some of the students faced challenges while preparing research papers for journals and conferences.

iii. Due above mentioned challenges, these students felt burden.

To overcome above mention challenges, RIT put forth following steps from 2018-19.

i. Institute decided to do proper planning of research project in seventh semester. Students were insisted to complete some of the project task in seventh semester like, literature review, analysis of data collected, experimental set up preparation etc.

ii. Institute allotted Ph.D. Completed faculties as a guide and conducted sessions on how to write Journal papers.

iii. Students were counselled regarding time management of the project and evaluated these students thrice in a semester. Some of the students allowed to do projects under sponsorship category at other organizations like IIT, NIT, DRDO, BARC etc.

C. Implementation and Challenges in ED track 
Students in certain engineering disciplines such as Electrical, Civil and Mechanical engineering were found to participate in entrepreneurship education at higher rates than others. For these students, ED track helped to develop career as an entrepreneur. Institute faced following challenges while implementing ED track.

i. Getting financial support for business start-up was major challenge for students as well as institute.

ii. Students found Confused in business ideas and scared to take the risk.

iii. Initially, major challenge was guidance to students because all guides were faculties of the institute.

To overcome above mention challenges, RIT put forth following steps from 2018-19.

i. Institute approached financial agencies to get financial support to start ups. RIT provided financial support to students.

ii. Conducted sessions of successful Entrepreneurs

iii. Trained some of the RIT faculties to guide students.

\section{Implementation and Challenges in CP track}

It is regular conventional track. Students who wish to prepare for GATE, CAT exams, this can be a suitable track for them. Institute faced following challenges while implementing CP track.

i. Students were expected to work in a team of four. To maintain proper coordination among the students and develop ability to work in team were a big challenges. Initially, it was observed that, some students were taking efforts, and some were engaged less.

ii. Conflicts in the thought process and burden to complete the project was also, a major challenge observed in CP track.

To overcome above mention challenges, RIT put forth following steps from 2018-19.

i. It was decided to conduct evaluation of students thrice in a semester. Evaluation rubrics were designed. In this rubric, focus is given to the team work aspect.

ii. Students were counselled regarding time management of the project.

iii. Students were instructed to maintain work diary to check the daily progress of the project. This helped to reduce the burden on the students.

\section{Results and Discussions}

Implementation of four track project system for Engineering students helped to improve their skill sets and performances in various competitive exams and campus placements.

A. Industry internship and project (IIP)

To determine the extent to which students succeeded to relate theory with practices. Questionary was prepared and responses from 500 students and their mentors were collected.

1) Correlate skills taught at institute with actual practice:
Students were asked to rate the usefulness of the skills they were taught at institute in performing the duties they were given during internship. Figure no. 2 shows that, $270(54 \%)$ of the students rated the skills they were taught in a institute as useful and $195(39 \%)$ as very useful while $35(7 \%)$ said the skills were not useful. This implies that the skills taught at the institute are relevant and useful to the industry for the majority of the students. Almost 93\% students could apply skill sets like effective communication, work ethics, work life balance, creativity, team work, pressure management, data modelling and analysis etc.

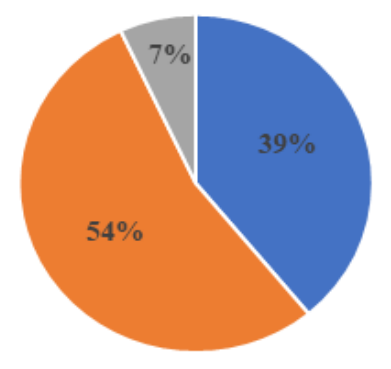

- Very useful $\mid$ Useful $=$ Not useful

Fig.2 Correlate skills taught at institute with actual practice

\section{2) Development of technical skills in students:}

Based on evaluation of internships thrice in the semester and survey of 100 mentors, following conclusions were made. Figure no. 3 shows the responses of institute mentors regarding development of technical skill in the students. $21 \%$ of the mentors said technical skill was excellent, $41 \%$ mentors said it was good, $23 \%$ mentors said technical skill was average and remaining $16 \%$ replied that technical skills in students were poor. Being rated as average and relatively poor by the majority of the mentors implies that the industry was not happy with these students. The reason why the student's development of basic technical skills was rated poor and average could be due to inadequate time allocated for practice in the curriculum. With less time allocated for practical skills training, the students cannot be able to master the basic technical skills to the expectations of the industry. Hence, RIT decided to start project based learning from first year to final year. For first year students institute added Engineering exploration course in the curriculum. This course develops the student to work in interdisciplinary streams. This is one of the steps towards experiential learning. Institute focused more on Engineering practice laboratory to enhance the skills of the students in actual engineering practices. For second year students environmental project and for third year students mini project is added in the curriculum. 


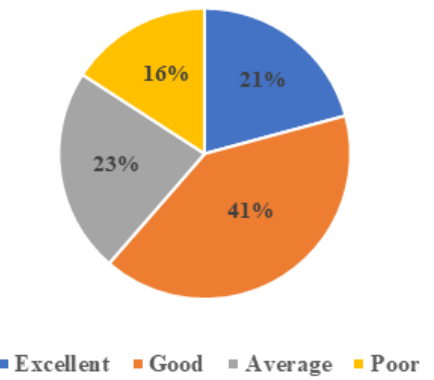

Fig.3 Development of technical skills in students

\section{3) Performance of students in Campus placement:}

Implementation of four track system for engineering students helped to improve their performance in various competitive exams and campus placement drives. In the year 2018-19, a Pool campus drive was conducted by a leading MNC. This industry recruited 56 candidates, out of which 28 candidates were from RIT. Furthermore, the selection percentage in a specific company has escalated by $15-20 \% .72 \%$ of students working under IIP choice were retained for job in the same company where they completed internship. While, remaining $25 \%$ students are already been placed in other companies or have shown interest for higher studies.

From academic year 2017-18 to 2019-20 total 643 students selected IIP track. Placement of institute has been increased from $63.05 \%$ to $89.70 \%$ in last three years. Placement statistics is shown in the figure no. 4 .

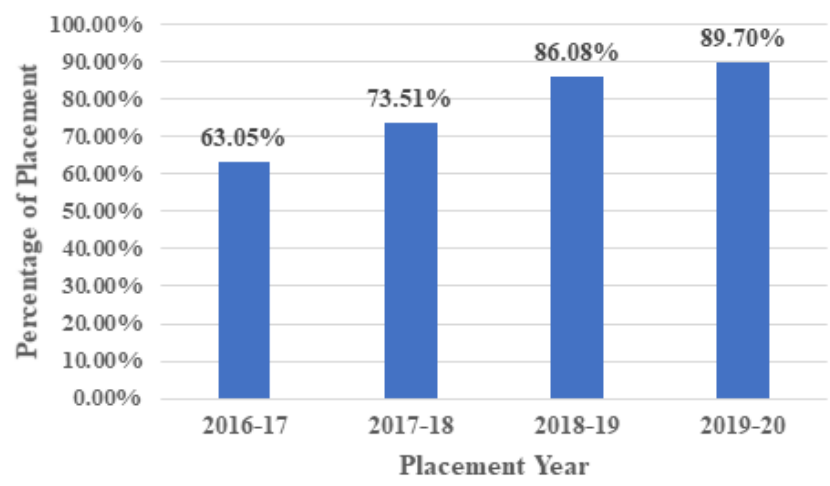

Fig.4 Placement statistics

B. Undergraduate research experience (URE)

Education through research projects has a positive effect on student knowledge and the development of skills such as collaboration, critical thinking, and problem solving which increases their motivation and engagement. A Questionary was prepared for URE opted students to rate themselves regarding development of self-learning ability, apply facts and principals in research, development of critical thinking ability, improvement in the confidence level in problem solving ability. 40 students were involved in this survey. Responses observed from this survey are shown in Table no.1.

Poor responses in each criterion was observed due to extra burden taken by students regarding completion of research, poor fundamentals, less connect with research guides etc. From 2017-18 to 201920 students who had opted URE track, secured admissions for Masters in abroad. This could happen because, students developed their resumes from research point of view.

Table 1. Response of URE opted students

\begin{tabular}{|l|c|c|c|c|}
\hline \multicolumn{1}{|c|}{ Response } & $\begin{array}{c}\text { self-learning } \\
\text { ability }\end{array}$ & $\begin{array}{c}\text { apply facts and } \\
\text { principals in research }\end{array}$ & $\begin{array}{c}\text { Development of } \\
\text { critical thinking } \\
\text { ability }\end{array}$ & $\begin{array}{c}\text { Improvement in } \\
\text { the confidence level } \\
\text { in problem solving }\end{array}$ \\
\hline Excellent & $25 \%$ & $40 \%$ & $10 \%$ & $50 \%$ \\
\hline Good & $38 \%$ & $30 \%$ & $30 \%$ & $40 \%$ \\
\hline Average & $29 \%$ & $25 \%$ & $40 \%$ & $8 \%$ \\
\hline Poor & $8 \%$ & $5 \%$ & $20 \%$ & $2 \%$ \\
\hline
\end{tabular}

C. Entrepreneurship Development (ED)

Survey of ED track mentors were conducted related to interest and involvement of students in entrepreneurship, attitudes toward entrepreneurship as a career option, how this involvement relates to student's entrepreneurial selfefficacy, and the characteristics of students who participated in this track (Duval-Couetil et al.,2010) (Wang and Kleppe,2001). Figure no. 5 to 9 indicate the responses given by mentors after evaluation of ED track opted students and conducting survey. Evaluation of students from 2017-18 to 2019 were considered for this survey.

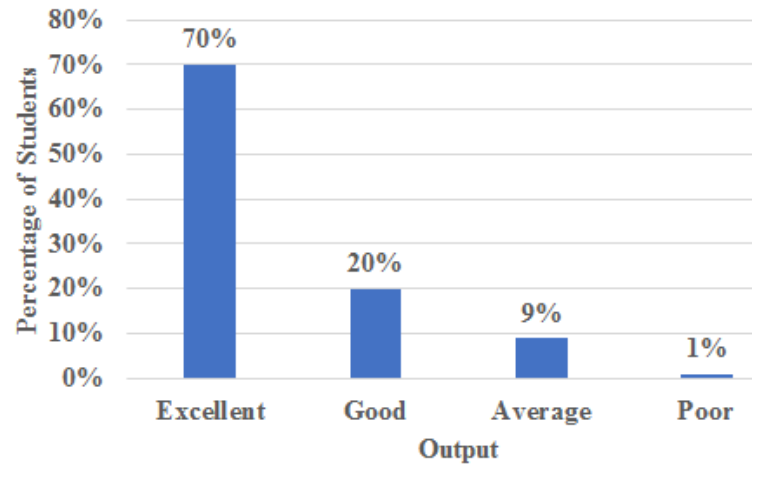

Fig.5 Interest and involvement students in entrepreneurship 


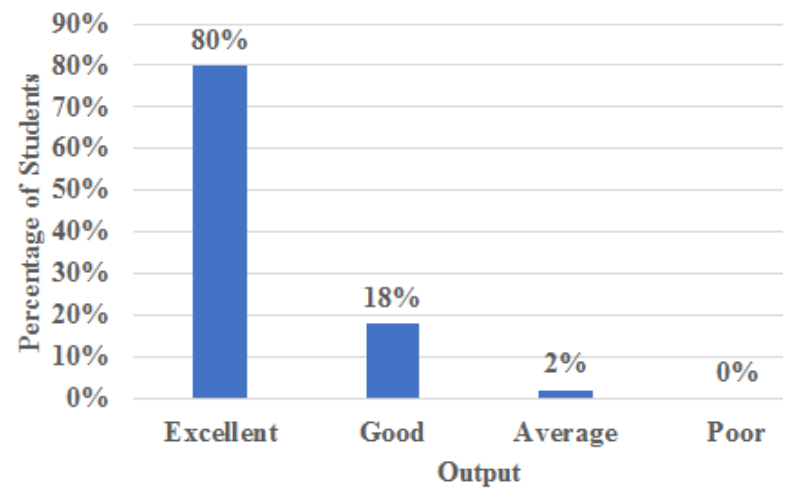

Fig.6 Attitudes toward entrepreneurship as a career option

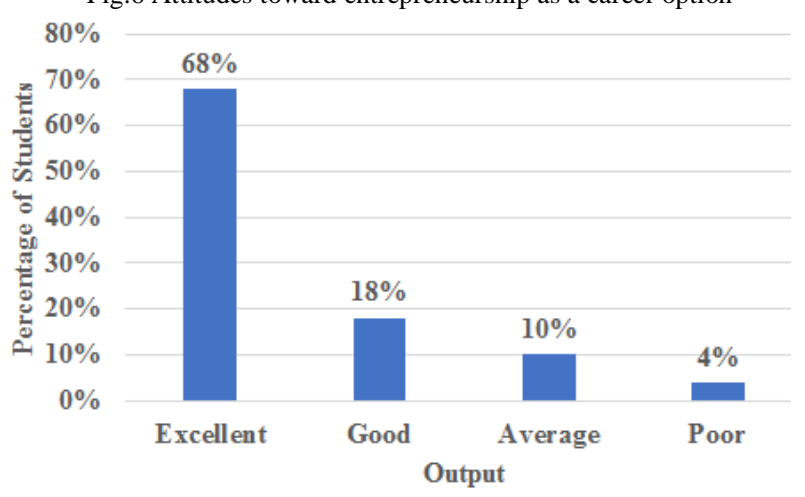

Fig.7 Characteristics of students who participated in ED track

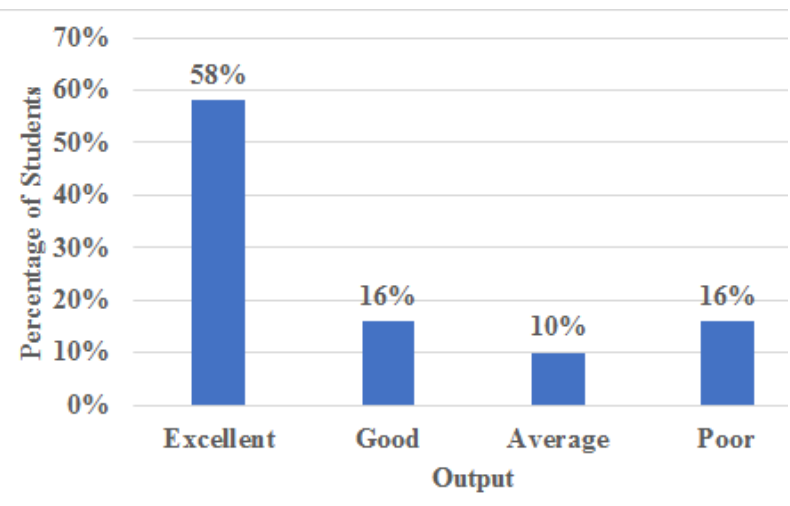

Fig.8 Involvement relates to students' entrepreneurial self-efficacy
Overall output of ED track regarding involvement of students and their attitude towards Entrepreneurship was satisfactory. The entrepreneurial self-efficacy is the perception of the confidence of the entrepreneurs in themselves in their own entrepreneurial capacities, before they are laid out to launch out in the business (Gol et al.,2001). Output regarding this is observed as an unsatisfactory. The reason for this is societal pressure on the student and family regarding career and growing competition in the market.

19 students of RIT have started their business from 2017-18. These start-ups are of small scale. 11 students have joined the business which is run by their family. 25 students are in the process of starting the business due to lack of financial support. 13 students, who had opted ED track diverted their mind towards different career opportunities.

\section{Regular Capstone Project (CP)}

1 Skill sets developed in students under CP track:

To rate the outcomes and find the lacunae in the CP track, survey of 500 students was carried out. Questionary designed in the survey was based on skill sets developed in the students i.e. team work, project management, apply theory learned while developing product, innovation, leadership, time management etc. (Chandrasekaran et al.,2012) (Blicblau and Steiner, 1998). Responses given by students who opted CP track are given in table no. 2. Based on the survey and evaluation of the students, it was observed that skill sets like apply theory to project, time management, and project management were satisfactorily attained. Accomplishment of outcomes like team work, leadership were less satisfied. This ensued due to less coordination among the students. Institute worked on this lacuna. Institute guides worked on team coordination with frequent meeting and follow up with the students. Workshops were conducted to motivate and guide students regarding team work.

Table 2 Responses given by students who opted CP track

\begin{tabular}{|l|c|c|c|c|c|c|}
\hline \multirow{2}{*}{ Response } & Team Work & $\begin{array}{c}\text { project } \\
\text { management }\end{array}$ & $\begin{array}{c}\text { Apply } \\
\text { theory }\end{array}$ & Innovation & $\begin{array}{c}\text { Time } \\
\text { management }\end{array}$ \\
\hline Excellent & $20 \%$ & $30 \%$ & $80 \%$ & $10 \%$ & $30 \%$ \\
\hline Good & $53 \%$ & $60 \%$ & $19 \%$ & $30 \%$ & $43 \%$ \\
\hline Average & $10 \%$ & $7 \%$ & $1 \%$ & $50 \%$ & $20 \%$ \\
\hline Poor & $17 \%$ & $3 \%$ & $0 \%$ & $10 \%$ & $7 \%$ \\
\hline
\end{tabular}

\section{Conclusion}

RIT, Rajaramnagar, implemented choice based four-track project system for final year engineering students from the academic year 2017-18. These four choices are industry internship and projects (IIP), undergraduate research experience (URE), Entrepreneurship development (ED), Capstone project (CP). During the implementation of this project system, institute and students faced many challenges. Major challenges comprise sufficient number of industries for internships, burden in the students to complete 
URE projects, Lack of financial support for start-ups and confusion in business ideas under ED track, lack of coordination in the project team etc. Institute has overcome these challenges. Surveys of the students and faculties were conducted to study the outcomes of the four-track project system. Major achievements of this system are given below.

i. Under IIP track, students succeeded to correlate theories learned with actual practice. Technical knowledge of students is improved. Students learned various industrial skills like work ethics, time management, work life balance etc. Placement of institute has been increased from $63.05 \%$ to $89.70 \%$ in last three years. More than $72 \%$ interns have been offered jobs by same company, where they completed internship.

ii. Under URE track, students developed skills like critical thinking, self-learning and applying facts and principals to research. These students developed their resume from research point of view. Moreover, twenty students who opted URE track have secured admissions for Masters in abroad.

iii. Under ED track, students developed entrepreneurial self-efficacy and entrepreneurial characteristics. Nineteen students started business and Twenty-one students joined the business of their parents in last three years.

iv. Under CP track, students learned skills like teamwork, leadership, innovation and time management.

\section{Acknowledgement}

We would like to show our gratitude towards the management of RIT, Rajaramnagar for continuous support and motivation for this research. We thank all faculty members and Training \& placement team of the RIT, Rajaramnagar who provided insight and expertise that greatly assisted the research.

\section{References}

1. Gashaw, Z. (2019). Challenges facing internship programme for engineering students as a learning experience: a case study of Debre Berhan University in Ethiopia. IOSR Journal of Mechanical and Civil Engineering (IOSRJMCE), 16(1), 12-28.

2. Waychal, P. (2016). Innovating final year (capstone) projects in engineering education. Journal of Engineering Education Transformations, 30(1), 26-29.

3. Jung, J., \& Lee, S. J. (2017). Impact of internship on job performance among university graduates in South Korea. International Journal of Chinese Education, 5(2), 250-284.

4. Lutz, F. C., \& Schachterle, L. (1996). Projects in undergraduate engineering education in America. European Journal of Engineering Education, 21(2), 207-214.

5. Parishani, N., \& Khorooshi, P. (2016). Challenges and Opportunities of Internship Lessons in the View of Students from Farhangian University Case Study: Colleges of Pardis Fatemeh Zahra and
Shahid Rajai in Esfahan. Mediterranean Journal of Social Sciences, 7(5), 143

6. Renganathan, S., Karim, Z. A. B. A., \& Li, C. S. (2012). Students' perception of industrial internship programme. Education+ Training.

7. Gol, O., Nafalski, A., \& McDermott, K. (2001, October). The role of industry-inspired projects in engineering education. In 31st Annual Frontiers in Education Conference. Impact on Engineering and Science Education. Conference Proceedings (Cat. No. 01CH37193) (Vol. 2, pp. F3E-1). IEEE.

8. Gerba, D. T. (2012). Impact of entrepreneurship education on entrepreneurial intentions of business and engineering students in Ethiopia. African Journal of Economic and Management Studies.

9. Duval-Couetil, N., Reed-Rhoads, T., \& Haghighi, S. (2012). Engineering students and entrepreneurship education: Involvement, attitudes and outcomes. International Journal of Engineering Education, 28(2), 425.

10. Duval-Couetil, N., Reed-Rhoads, T., \& Haghighi, S. (2010, October). Development of an assessment instrument to examine outcomes of entrepreneurship education on engineering students. In 2010 IEEE Frontiers in Education Conference (FIE) (pp. T4D-1). IEEE.

11. Wang, E. L., \& Kleppe, J. A. (2001). Teaching invention, innovation, and entrepreneurship in engineering. Journal of Engineering Education, 90(4), 565-570.

12. Täks, M., Tynjälä, P., Toding, M., Kukemelk, H., \& Venesaar, U. (2014). Engineering students' experiences in studying entrepreneurship. Journal of engineering education, 103(4), 573-598.

13. Kim, M., \& Park, M. J. (2019). Entrepreneurial education program motivations in shaping engineering students' entrepreneurial intention. Journal of Entrepreneurship in Emerging Economies.

14. Chandrasekaran, S., Stojcevski, A., Littlefair, G., \& Joordens, M. (2012, January). Learning through projects in engineering education. In SEFI 2012: engineering education 2020: meet the future: proceedings of the 40th SEFI annual conference 2012. European Society for Engineering Education (SEFI).

15. Blicblau, A. S., \& Steiner, J. M. (1998). Fostering creativity through engineering projects. European Journal of Engineering Education, 23(1), 55-65. 